\title{
Immobilization of Amylase by Entrapment Method in Different Natural Matrix
}

\author{
Majneesh Chaudhary ${ }^{1}$, Neerja Rana ${ }^{1}$, Devina Vaidya ${ }^{2}$, Arti Ghabru ${ }^{1}$, \\ Kavita $\operatorname{Rana}^{1 *}$ and Bhawna Dipta ${ }^{1}$
}

\author{
${ }^{1}$ Department of Basic Sciences, Microbiology Division, ${ }^{2}$ Department of Food Science and \\ Technology, Microbiology Division, Dr Y.S. Parmar University of Horticulture and Forestry, \\ Nauni, Solan, Himachal Pradesh-173230, India
}

*Corresponding author

\section{A B S T R A C T}

\section{Keywords \\ Amylase, Immobilization, Purification, Entrapment, Alginate \\ Article Info \\ Accepted: \\ 12 April 2019 \\ Available Online: \\ 10 May 2019}

\begin{abstract}
The use of enzymes in a free form is very uneconomical because the enzymes generally cannot be recovered at the end of the reaction. These drawbacks can be overcome by immobilization of the enzyme thereby rendering it more stable and easy to recover and recycle. It is a very effective alternative for gripping the problems of instability, repetitive use and reduction in the cost of enzyme. The aim of this research was to obtain the optimum condition of the making of immobilized amylase beads using a different natural matrix. The result obtain that amylase producing isolate i.e. isolated from hot water spring and was precipitate with ammonium sulphate with specific activity of $45.29 \mathrm{IU} / \mathrm{mg}$ and 1.43 fold purification. The purified amylase was immobilized by entrapment method with $3 \%$ concentration of sodium alginate and agar with immobilization yield of $72.18 \%$ and $34.89 \%$ for isolate MW2 and $0.25 \%$ chitosan concentration gave $66.45 \%$ immobilization yield. Hence, we propose that, this method can be used to produce immobilized amylase which can be used in various areas such as diagnostics, food, medicine and cosmetics.
\end{abstract}

\section{Introduction}

Among the enzymes, amylase are most widely used industrial enzyme that exhibit great significance having approximately $65 \%$ of the world enzyme market (Ali et al., 2017) Amylases have attracted global enzyme market due to their vast applications in starch processing, detergent, alcohol, textile, food, paper and pharmaceutical industries (Mageswari et al., 2012 and Couto and Sanroman, 2006). The $\alpha-$ amylase (EC
3.2.1.1) are extracellular enzymes which catalyzes random cleavage of the $\alpha-1,4$ glycosidic bonds between adjacent glucose molecules inside the linear amylose chain of starch. The amylases can be obtained from various natural resources such as plants, animals and microorganisms (Saranraj and Stella, 2013). The microbial production of amylase is more effective than the other sources as the technique is easy, cost effective, consistent and fast which can be modified to obtain enzymes of desired 
characteristics (Tanyildizi et al., 2005). The major concern in an enzymatic process is the instability of the enzyme under repetitive use and inhibition by high substrate and product concentration. Immobilization is a very effective alternative in overcoming problems of instability and repetitive use of enzymes. The term 'immobilized enzymes' refers to 'enzymes physically confined or localized in a certain defined region of space with retention of their catalytic activities which can be used repeatedly (Tosa,1966). Immobilization provides a separation of enzyme from the product which minimizes the protein contamination (Saifuddin et al., 2013). It also remarkably reduces the cost of enzyme and enzymatic products. Immobilization of enzyme by attachment to a matrix imparts rapid arrest of the reaction by removal of the enzyme from the reaction solution and improvement of enzyme stability against temperature, solvents, $\mathrm{pH}$, contaminants and impurities (Tian et al., 2009). It also helps in efficient recovery and reuse of expensive enzymes (Sheldon, 2007).

Generally, enzymes are immobilized by physical adsorption, ionic binding, covalent binding, cross linking, encapsulation and entrapment methods (Hassan et al., 2016). Entrapment is defined as an irreversible method of enzyme immobilization where enzymes are entrapped in a support or inside fibers, either in lattice structure of a material or polymer membranes that allow the substrate and products to pass through but retains the enzyme (Klotzbach et al., 2008). The nature of the solid support or matrix plays an important role in retaining the actual confirmation and activity of enzyme in the processes that utilize immobilized biocatalysts (Riaz et al., 2009). Mostly, natural polymers such as alginate, chitosan and agar are widely used in enzyme immobilization because the gel formation with these polymers occurs at mild conditions, with low cost. (Devi et al., 2012).Typically, entrapment can improve mechanical stability and minimize enzyme leaching. The enzyme does not chemically interact with the polymer. Therefore, denaturation is usually avoided (Shen et al., 2011).

Therefore, the present study was mainly focused on amylase produced from MW2 isolated from hot water spring and immobilization by entrapment method in different natural matrix.

\section{Materials and Methods}

Amylase producing bacterial isolate i.e. MW2 was isolated from hot water spring of Manikaran, Kullu, Himachal Pradesh.

\section{Production and Partial Purification of Amylase}

The culture was inoculated in standardized enzyme production media. The flasks were incubated at $45 \pm 2^{\circ} \mathrm{C}$ for $72 \mathrm{~h}$. The culture contents of the MW2 were centrifuged at $10,000 \mathrm{rpm}$ for $10 \mathrm{~min}$ at $4^{\circ} \mathrm{C}$. Cell free supernatant as crude enzyme extract thus obtained was collected. The cell free crude extracts of the enzyme was subjected to sequential ammonium sulphate saturations and dialysis, concentrated enzyme was kept at $4^{\circ} \mathrm{C}$ for further application.

\section{Immobilization of partial purified amylase}

\section{Immobilization by using sodium alginate (Rajagopalan and Krishnan, 2008)}

The immobilization of enzyme was done by using sodium alginate. In this method 1, 2, 3 and $4 \%$ solution of sodium alginate was prepared in $0.1 \mathrm{M}$ phosphate buffer $(\mathrm{pH} 7)$. After cooling down to room temperature, $1 \mathrm{ml}$ of enzyme stock solution was mixed with 9 
$\mathrm{ml}$ of sodium alginate solution. The mixture was then suspended drop wise into pre-chilled $0.1,0.2,0.3,0.4$ or $0.5 \mathrm{M}$ calcium chloride solution with gentle stirring at $4^{\circ} \mathrm{C}$ for $2 \mathrm{~h}$. The formed beads were recovered by filtration and thoroughly washed with distilled water. These beads were then stored in $0.1 \mathrm{M}$ phosphate buffer $(\mathrm{pH} 7.0)$ at $4^{\circ} \mathrm{C}$. The filtered calcium chloride solution was collected for enzyme activity determination.

\section{Immobilization by using agar (Matsunga $e t$ al., 1980)}

The immobilization of enzyme was done by using agar as material. In this method $0.5,1$, 2,3 and $4 \%$ solution of agar solution was prepared in $0.1 \mathrm{M}$ phosphate buffer $(\mathrm{pH} 7.0)$ by warming them at $50^{\circ} \mathrm{C}$. After cooling down to room temperature, $1 \mathrm{ml}$ enzyme was mixed with $9 \mathrm{ml}$ agar solution (the total volume of matrix and enzyme mixture being $10 \mathrm{ml}$ ) and immediately casted on preassembled glass plates. After solidification at room temperature, the gel was cut into small beads of $5 \times 5 \mathrm{~mm}$ size and washed several times before use to remove any enzyme attached to the gel surface the beads were stored in $0.1 \mathrm{M}$ phosphate buffer $(\mathrm{pH} 7)$ and at $4{ }^{\circ} \mathrm{C}$. After immobilization, the retained activity and immobilization yield was calculated according to the following equation:

$$
\begin{gathered}
\text { Immobilized amylase activity }(\mathrm{IU} / \mathrm{g})=\frac{\text { Enzyme activity of immobilized beads }}{\text { Quantity of beads }} \\
\text { Retained activity yield }(\%)=\frac{\text { Yield of immobilized enzyme }}{\text { Yield of free enzyme }} \times 100 \\
\text { Immobilization yield }(\%)=\frac{\text { Total activity of enzyme in immobilized gel }}{\mathrm{A}-\mathrm{B}} \times 100
\end{gathered}
$$

Where $\mathrm{A}$ is activity of free enzyme added and $B$ is the activity of remaining enzyme in filtered calcium chloride solution.

\section{Chitosan-covered beads (Zhau et al., 2010)}

After the beads were formed with above method, these beads was dipped in $0.25 \%$ solution of chitosan and kept under mild shaking for $30 \mathrm{~min}$. The formed beads were recovered by filtration and thoroughly washed with distilled water. These beads were then stored in $0.1 \mathrm{M}$ phosphate buffer ( $\mathrm{pH} \mathrm{7.0)}$ at $4^{\circ} \mathrm{C}$.

\section{Results and Discussion}

Amylase producing bacterial isolate i.e. MW2 was isolated from hot water spring of Manikaran, Kullu, Himachal Pradesh.

\section{Production and partial purification of amylase}

The isolate got precipitated with $0-80 \%$ ammonium sulphate with increased specific activity to $45.29 \mathrm{IU} / \mathrm{mg}$. The fold purification was increased to 1.43 and with $76 \%$ purification for MW2 (Table 1). It was found that the dialysis further concentrated the amylase with specific activity of $58.62 \mathrm{IU} / \mathrm{mg}$ with 1.85 fold of purification.

Bukhari and Rehman (2015) purified Bacillus subtilis with ammonium sulphate precipitation $(80 \%)$ and the purified amylase could be detected as a single band of $59 \mathrm{kDa}$ by SDS polyacrylamide gel electrophoresis. Kohli et al., (2016) also purified enzyme with 75 per cent ammonium sulphate with 21 fold 
of purification. El-Kady et al., (2017) isolated and purified thermophilic Bacillus $s p$. NRC12017. They purified alpha amylase by 60-80 per cent ammonium sulphate precipitation.

\section{Immobilization of Partial Purified Amylase}

\section{Immobilization by using sodium alginate}

Immobilization of amylase with $3 \%$ concentration of sodium alginate gave maximum activity of $87.78 \mathrm{IU} / \mathrm{g}$ with highest yield of $72.18 \%$ [Fig. 1(a) and Plate 1(a)]. With the increase in concentration of sodium alginate there was increase in the immobilization yield. However the reduction in yield was noticed beyond $3 \%$. It was also found that at $1 \%$ sodium alginate no beads were formed. Several workers have used calcium alginate for immobilization of enzymes. Alginate is the one of supporting matrix that can be used for immobilization of enzyme. The main advantages of this matrix are non-toxic, high stability, high porosity, simple procedure for immobilization and relatively cheap (Anwar et al., 2009). Pore size of the beads should be such that substrate and product can easily diffuse in and out of the alginate gel matrix but the enzyme should retain in the micro environment of beads (Riaz et al., 2009).

\section{Immobilization by using agar}

Different concentration (0.5-4\%) of agar for entrapment of partial purified amylase for immobilization in which $3 \%$ of agar concentration gave highest immobilization yield of $34.89 \%$ for MW2 [Fig. 1(b) and Plate $1(b)]$. At lower concentration $(0.5 \%)$ of agar no cubes were formed and subsequently yield increased with the increase in concentration of agar. However, at $4 \%$ concentration the agar started solidifying before the addition of enzyme and gave low activity and yield.
Agar is another natural polymer used as matrix for the immobilization of enzymes. It is acid stable and shows no reactivity with protein. It is less costly as compared to other materials (Prakash and Jaiswal, 2011). Sharma et al., (2014) reported that at the lower concentration of agar, calcium chloride and shorter hardening time, beads get ruptured during decantation and washing of beads. They also reported that calcium agar beads prepared with $3 \%(\mathrm{w} / \mathrm{v})$ agar and 75 $\mathrm{mM}$ calcium chloride and hardened for 20 min were physically stabile with entrapment efficiency $(80 \%)$.

\section{Chitosan-covered beads}

The immobilization yield in alginate-chitosan $[0.25 \%(\mathrm{w} / \mathrm{v})]$ covered beads was $66.45 \%$ for MW2 (Plate 1(c)). It was evident from the data that the chitosan covered beads lowered the activity and immobilization yield for both the isolates. Chitosan is a linear polysaccharide which is used as the external layer of the immobilized beads. Alginate and chitosan which are polysaccharide biopolymers used in enzyme encapsulation (Zhou et al., 2010). When calcium alginate is mixed with chitosan, a strong ionic interaction occurs between the amino groups of chitosan and carboxyl groups of alginate for the formation of a polyelectrolyte complex (PEC) which results in better mechanical properties of the support (Ngah and Fatinathan, 2008; Rodrigues, 2008; Shu and Zhu, 2002; Xu et al., 2007). Oliveira et al., (2018) also reported that lower yield with chitosan covered beads suggested that this may be due to the excessive amount of support causing lose accessibility of amylase to the substrate.

In conclusion, amylases are extensively used in industrial applications like starch modification and food processing. Amylase producing bacteria was isolated from hot water spring. 
Table.1 Partial purification summary of amylase from bacterial isolate i.e. MW2.

\begin{tabular}{|c|c|c|c|c|}
\hline Purification Step & $\begin{array}{c}\text { Total Amylase } \\
\text { activity } \\
\text { (IU) }\end{array}$ & $\begin{array}{c}\text { Specific } \\
\text { Activity } \\
\text { (IU/mg) }\end{array}$ & $\begin{array}{c}\text { Fold } \\
\text { Purification }\end{array}$ & $\begin{array}{c}\text { Percent } \\
\text { Purification } \\
\text { (\%) }\end{array}$ \\
\hline $\begin{array}{c}\text { Ammonium } \\
\text { Sulphate } \\
\text { fractionation } \\
\text { (0-80\%) }\end{array}$ & 263.16 & 45.29 & 1.43 & 76 \\
\hline Dialysis & 235.69 & 58.62 & 1.85 & 68.07 \\
\hline
\end{tabular}

Total activity: Enzyme activity in given volume (IU)

Specific activity: Enzyme activity per unit protein concentration (IU/mg)

Purification fold: is increase in specific activity.

Percent purification: is remaining amylase activity as per cent of the initial amylase activity.

Fig.1 Effect of sodium alginate and agar concentration on amylase activity (IU/g) and immobilization yield $(\%)$

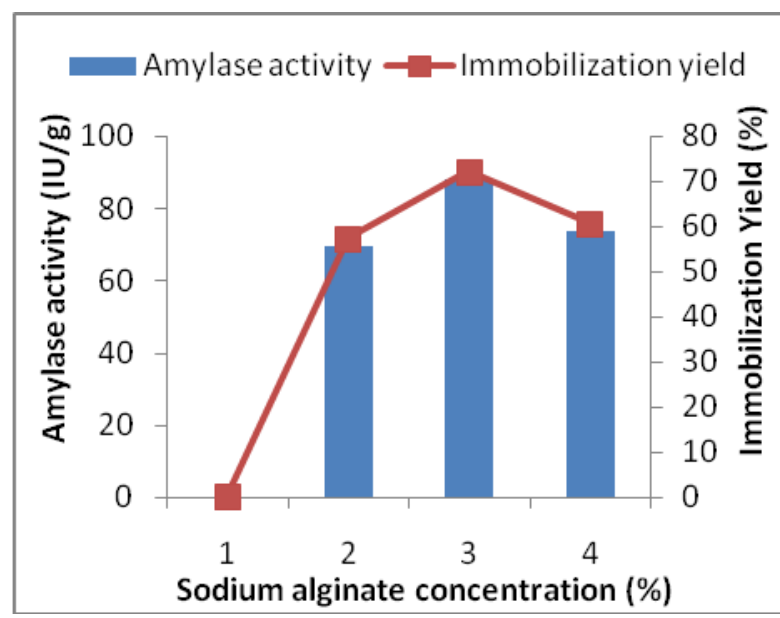

(a)

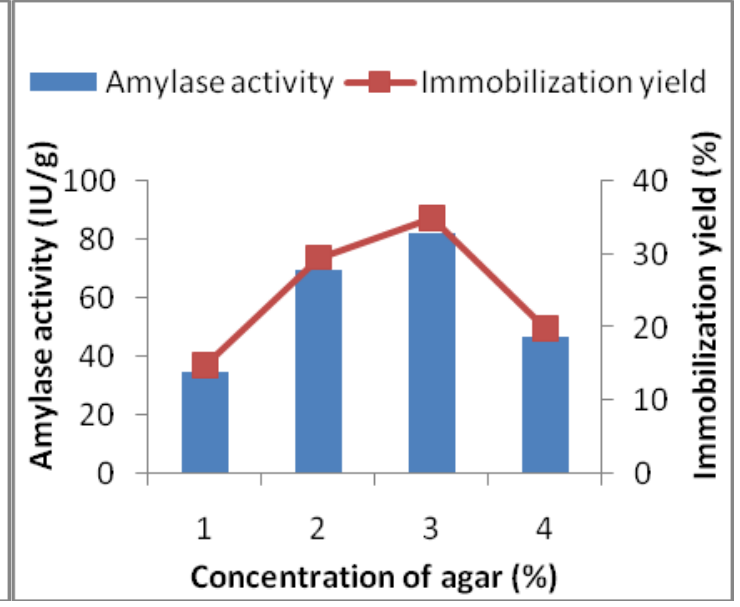

(b)

Plate.1 Beads formed by 3\% sodium alginate (a), 3\% agar (b) covering of $0.25 \%$ chitosan

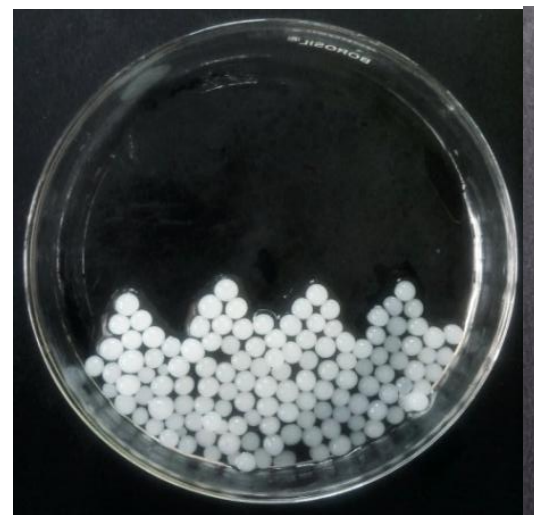

(a)

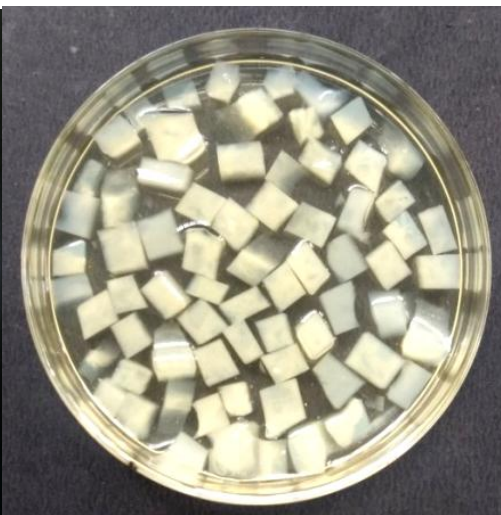

(b)

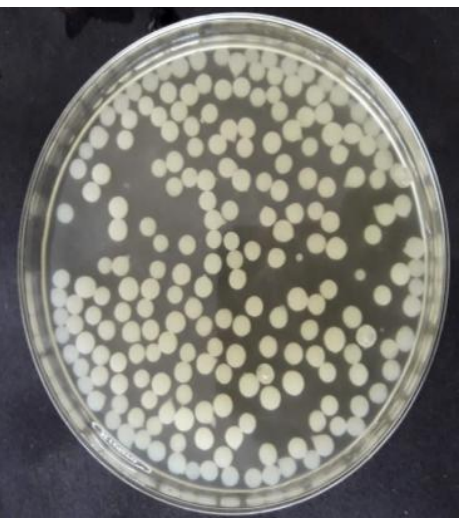

(c) 
The crude amylase was partially purified with ammonium sulphate fractionation with $68 \%$ recovery and immobilized by entrapment method on different matrices viz. alginate, chitosan and agar. Amylase immobilized in alginate matrix was found best matrix with maximum immobilization yield $72.18 \%$. It can be concluded that immobilized enzyme has potential to be explored in various starch and food industries.

\section{Acknowledgement}

ACRIP- PHET Solan center H.P-173230 (India) has been acknowledged by the author for providing financial assistance.

\section{References}

Ali EH, El-Nagdy MA, Al-Garni SM, Ahmed MS and Rawaa AM. 2017. Enhancement of alpha amylase product ion by Aspergillus flavus AUMC 11685 on mandarin (Citrus reticulata) peel using submerged fermentation. European Journal of Biological Research 7:154164.

Anwar A, Qader SAU, Raiz A, Iqbal S and Azhar A. 2009. Calcium Alginate: a support material for immobilization of proteases from newly isolated strain of Bacillus subtilis KIBGEHAS. World Applied Sciences Journal 7:1281-1286.

Bukhari DA and Rehman A. 2015.Purification and Characterization of $\alpha$-Amylase from Bacillus subtilis Isolated from Local Environment. Pakistan Journal of Zoology 47:905-911.

Couto SR and Sanroman MA. 2006. Application of solid state fermentation to food industry: a review. Journal of Food Engineering 76:291-302.

Devi B, Unni BG, Wann SB and Samanta R. 2012. Immobilization of partial purified alpha-amylase enzyme produced by soil born Bacillus species. Advances in applied science Research 3:2739-2744.

El-Kady EM, Asker MS, Hassanein SM,
Elmansy EA and El-Beih FM. 2017.Optimization, production, and partial purification of thermostable $\alpha$ amylase produced by marine bacterium Bacillus sp. NRC12017. International Journal of Pharmaceutical and Clinical Research 9:558-570.

Hassan ME, Tamer TM and Omer AM. 2016. Methods of enzyme immobilization. International Journal of Current Pharmaceutical Review and Research 7:385-392.

Klotzbach TL, Watt MM, Ansari Y and Minteer SD. 2008.Improving the microenvironment for enzyme immobilization at electrodes by hydrophobically modifying chitosan and Nafion polymers. Journal of Membrane Science 311:81-88.

Kohli I, Tulli R and Singh VP. 2016. Purification and characterization of maltose forming thermostable alkaline $\alpha$ amylase from Bacillus gibsonii S213. International Journal of Advanced Research 4: 356-366.

Mageswari A, Subramanian P, Chandrasekaran $\mathrm{S}$, Sivashanmugam $\mathrm{K}$, Babu $\mathrm{S}$ and Gothandam KM. 2012. Optimization and immobilization of amylase obtained from halotolerant bacteria isolated from solar salterns. Journal of Genetic Engineering and Biotechnology 10: 201-208.

Matsunga T, Karube I and Suzuki S. 1980.Entrapment of Clostridium butyricumin agar. Biotechnology and Bioengineering 22: 2607-2610.

Ngah WSW and Fatinathan S. 2008. Adsorption of $\mathrm{Cu}$ (II) ions in aqueous solution using chitosan beads, chitosan-GLA beads and chitosan-alginate beads. Chemical Engineering Journal 143:62-72.

Oliveira RL, Dia JL, Silva OS and Porto TS. 2018. Immobilization of pectinase from Aspergillus aculeatus in alginate beads and clarification of apple and umbu juices in a packed bed reactor. Food and Bioproduct Processing 109:9-18.

Prakash O and Jaiswal N. 2011. Immobilization of a thermostable $\alpha$-amylase on agarose 
and agar matrices and its application in starch strain removal. World Applied Sciences Journal 13: 572-577.

Rajagopalan G and Krishnan C. 2008. Immobilization of malto oligosaccharide forming $\alpha$-amylase from $B$. subtilis KCC103: properties and application in starch hydrolysis. Journal of Chemical Technology and Biotechnology 83:15111517.

Riaz QSAU, Anwar A and Iqbal S. 2009. Immobilization of a thermostable $\alpha$ amylase on calcium alginate beads from Bacillus subtilis KIBGE-HAR. Australian Journal of Basic and Applied Sciences 3: 2883-2887.

Saifuddin N, Raziah AZ and Junizah AR. 2013. Carbon nanotubes: a review on structure sand their interaction with proteins. Journal of Chemistry 1:776-815.

Saranraj P and Stella D. 2013. Fungal AmylaseA Review. International Journal of Microbiology Research 4:203-211.

Sharma M, Sharma V and Majumdar DK. 2014. Entrapment of $\alpha$-amylase in agar beads for biocatalysis of macromolecular substrate. International Scholarly Research Notices 2014:1-8.

Sheldon RA. 2007. Enzyme immobilization: the quest for optimum performance. Advanced Synthesis and Catalysis 349:1289-1307.

Shen Q, Yang R, Hua X, Ye F, Zhang W and Zhao W. 2011. Gelatin-templated biomimetic calcification for $\beta$ galactosidase immobilization. Process
Biochemistry 46:1565-1571.

Shu XZ and Zhu KJ. 2002. The release behavior of brilliant blue from calcium-alginate gel beads coated by chitosan: The preparation method effect. European Journal of Pharmaceutics and Biopharmaceutics 53:193-201.

Tanyildizi MS, Ozer D and Elibol M. 2005. Optimization of $\alpha$-amylase production by Bacillus sp. using response surface methodology. Process Biochemistry 40: 2291-2296.

Tian X, Anming $\mathrm{W}$, Lifeng $\mathrm{H}$, Haifeng L, Zhenming C, Qiuyan W and Xiaopu Y. 2009. Recent advance in the support and technology used in enzyme immobilization. African Journal Biotechnology 8: 4724-4733.

Tosa T, Mori T, Fuse N and Chibata I. 1966. Studies on continuous enzyme reactions. I. Screening of carriers for preparation of water-insoluble aminoacylase. Enzymologia 31:214-224.

Xu Y, Zhan C, Fan L, Wang L and Zheng H. 2007. Preparation of dual crosslinked alginate-chitosan blend gel beads and in vitro controlled release in oral site specific drug delivery system. International Journal of Pharmaceutics 336:329-337.

Zhou Z, Li G and Li Y. 2010.Immobilization of Saccharomyces cerevisiae alcohol dehydrogenase on hybrid alginatechitosan beads. International Journal of Biological Macromolecules 47:21-26.

\section{How to cite this article:}

Majneesh Chaudhary, Neerja Rana, Devina Vaidya, Arti Ghabru, Kavita Rana and Bhawna Dipta. 2019. Immobilization of Amylase by Entrapment Method in Different Natural Matrix. Int.J.Curr.Microbiol.App.Sci. 8(05): 1097-1103. doi: https://doi.org/10.20546/ijcmas.2019.805.126 